\title{
EFFECT OF D-TUBOCURARINE AND ANAESTHESIA UPON CARDIAC OUTPUT IN NORMAL AND HISTAMINE-DEPLETED DOGS*
}

\author{
Dochil LeE, M.D. AND D. L. Johnson, M.A.†
}

Curare, Administered durixg anaesthesia for its specific relaxant action, has often been accused of an unwanted effect of lowering the blood pressure. Soon after its clinical introduction, the suggestion was made that endogenously released histamine might be responsible for the hypotension..$^{1,2.3}$

Appreciable quantities of histamine are found in tissue mast cells ${ }^{4}$ grouped in connective tissue around the small vessels. These contain granules of heparin and histamine. Intragranular histamine remains inactive until granule membranes are ruptured by physical or chemical means, and then it becomes physiologically active. Histamine is known to be a powerful vasodilator of capillaries and small veins. ${ }^{1}$ The highest concentrations occur in skin, intestine, and lung, that is, at surfaces where the organism is in contact with external stimuli. ${ }^{\overline{5}}$ More recent studies indicate that curare triggers the release of some body stores of histamine in dogs. ${ }^{6,7}$

It was, therefore, proposed to study quantitatively the cardiovascular effects of curare and histamine. This was done by comparing the effect of curare in normal dogs with that of a similar injection in histamine-depleted dogs.

\section{Method}

Twenty-eight experiments were done in healthy mongrel dogs weighing from 11.5 to $20 \mathrm{~kg}$. Anaesthesia was induced with sodium thiamylal (Surital), 15-20 $\mathrm{mg} / \mathrm{kg}$ and the trachea was intubated. The animals were then maintained with 1 per cent halothane in oxygen from a Copper Kettle vaporizer. End-tidal halothane concentrations were monitored with an ultraviolet light analyzer. Animals were mechanically ventilated with a Harvard animal respirator. Aortic flow was measured with an electronagnetic flow probe, chronically implanted around the ascending aorta. The aortic flow wave was recorded and an integral of this wave form was triggered by the electrocardiogram QRs to obtain a measure of stroke volume for each heart beat, according to the technique of Scher. ${ }^{8}$

The femoral vein was cannulated for the injection of drugs. The femoral artery was cannulated for continuous monitoring of blood pressure with a Statham transducer. This also permitted anaerobic sampling of arterial blood for the determination of $\mathrm{pH}, \mathrm{PO}_{2}$, and $\mathrm{PCO}_{2}$. The heart rate was counted from the electrocardiogram.

* This study was supported in part by Washington State Heart Association, grant \#6667-8. Halothane was supplied by Ayerst Laboratories. Brocresine was supplied by Lederle Laboratories.

†Mr. Johnson is at Anaesthesia Research Laboratories, Providence Hospital, Seattle, Washington. Dr. Lee is now in Anaesthesia Research, Faculty of Medicine, University of Toronto. 


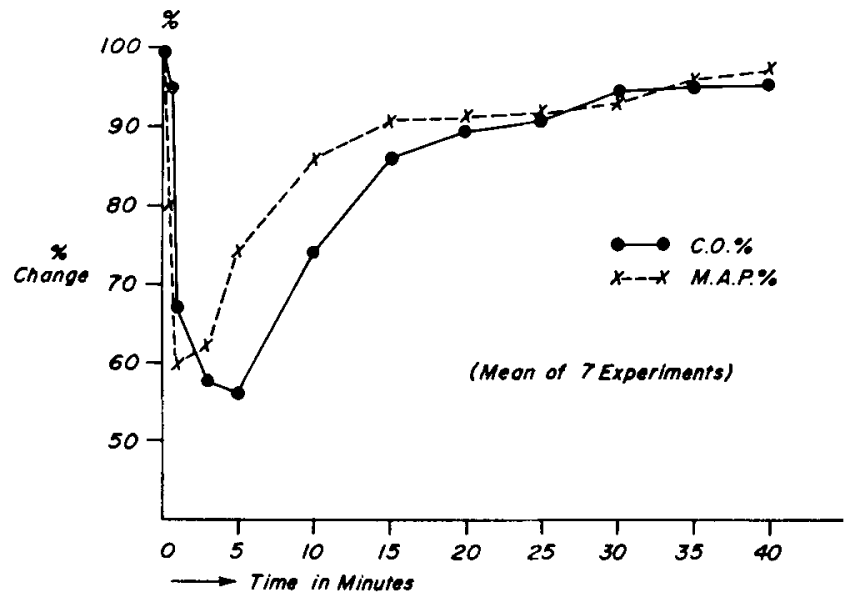

Figure 1. The mean cardiac output and mean arterial pressure from seven experiments following a dose of $0.25 \mathrm{mg} / \mathrm{kg}$ d-tubocurarine.

Histamine depleted dogs were prepared by giving "Brocresine" NSD 1055 (3hydroxy-4 bromobenzyl-oxamine), which is a histamine synthesis inhibitor. ${ }^{9}$ For each of five successive days a dose of Brocresine $75 \mathrm{mg} / \mathrm{kg}$ was given orally. A daily intravenous injection of curare $0.25 \mathrm{mg} / \mathrm{kg}$ was also given to deplete the body stores of histamine. ${ }^{9,2,1}$ This procedure should provide animals which are relatively free of histamine.

In subsequent experiments in four groups of dogs, mean arterial pressure and aortic flow were measured continuously for 40 minutes after injection and recorded with an Offner type RB dynograph. Esophageal temperature was $37 \pm 1^{\circ} \mathrm{C}$ as measured with a thermister probe and Yellow Springs telethermometer. A Godart capnograph was used to provide continual visual evidence that end-tidal $\mathrm{CO}_{2}$ was at normal level.

\section{Results}

\section{Effect of curare}

Injection of $0.25 \mathrm{mg} / \mathrm{kg}$ d-tubocurarine in seven dogs produced an immediate significant fall in mean arterial pressure to 60 per cent of the control in one minute after injection. A reduction in cardiac output to 56 per cent of the control at five minutes was followed by a slow recovery toward original values (Figure 1).

The drop in cardiac output after curare is due primarily to a reduction in stroke volume. Subsequent doses of curare do not produce a significant fall in these parameters (Figure 2), suggesting that some factor such as histamine no longer contributes to the effect.

Blood histamine levels were measured by the method of Shore ${ }^{10}$ in two experiments. The changes in the first minute after curare injection were slight, but 

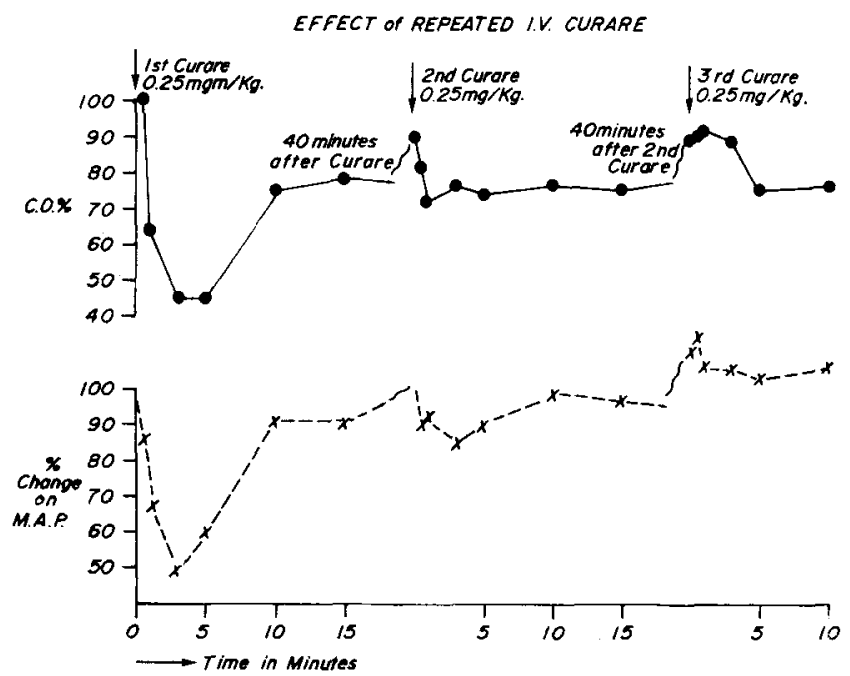

Figure 2. Subsequent doses of curare do not produce significant fall in either cardiac output or mean arterial pressure.

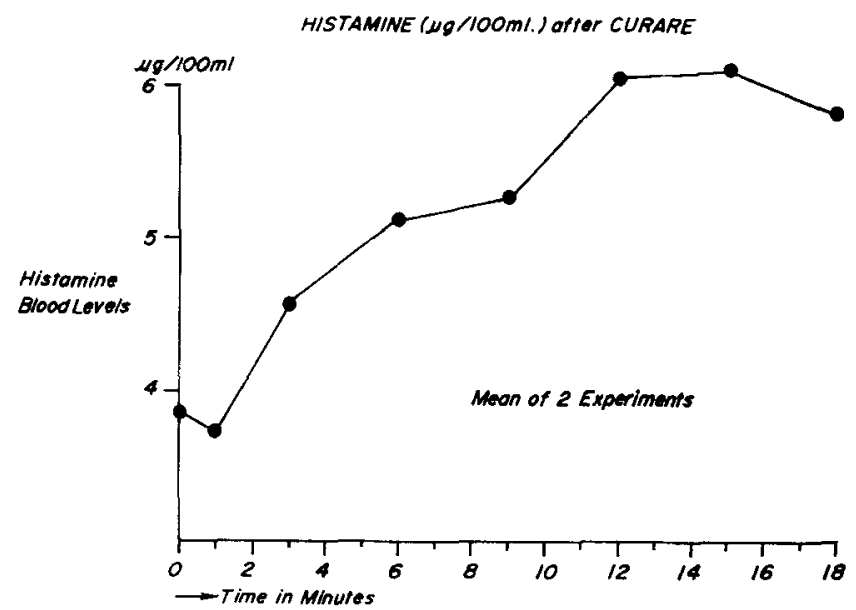

Figure 3. The average blood levels of histamine in two experiments.

gradually showed a significant increase to 160 per cent of the control values after 15 minutes (Figure 3).

Effect of histamine alone

The injection of $0.2 \mathrm{mg}$ of histamine in each of eight dogs produced a relatively uniform response of severe drop in mean arterial pressure ranging from 27 per cent to 60 per cent, with a mean of 40 per cent of the control level within 30 seconds, after which it returned to control levels within five minutes, followed by a slight rebound effect. The effect of histamine on cardiac output was less dra- 


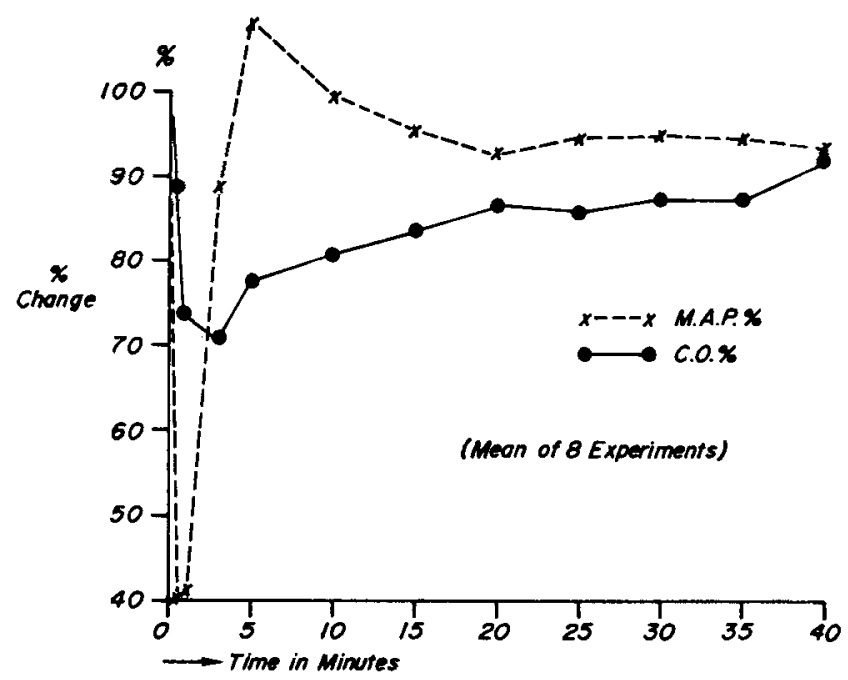

Figure 4. Cardiac output and mean arterial pressure after histamine.

COMPARISON OF CAROIAC OUTPUT FOLLOWING CURARE and HISTAMINE

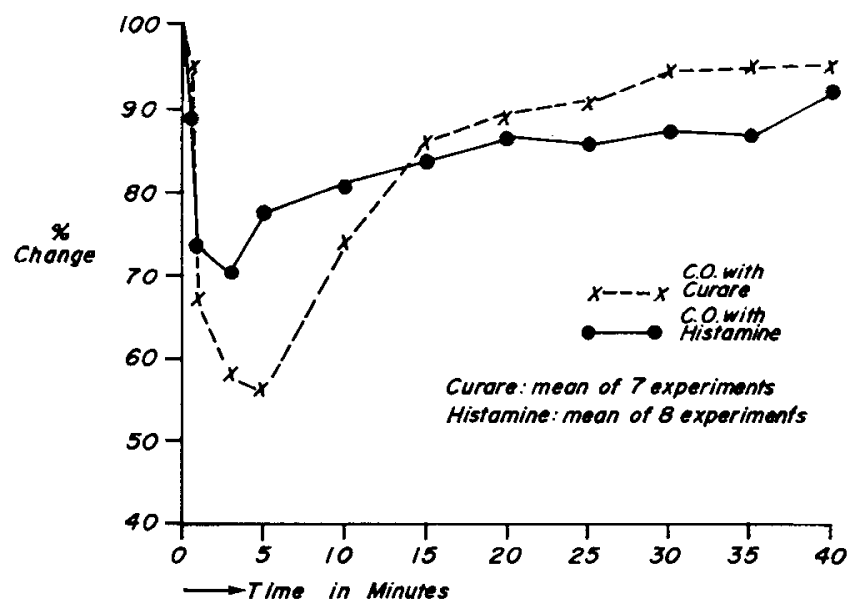

Ficure 5. Comparison of cardiac output folowing curare and histamine.

matic, it being reduced to 70 per cent of the control in three minutes, with a slow but incomplete return toward the control levels (Figure 4).

Thus, the effect of direct injection of histamine on cardiac output is less profound than that of curare, but the effect on mean arterial pressure is much more profound than curare (Figure 5 and Figure 6 ).

The effect of the antihistamine diphenhydramine hydrochloride (Benadryl ${ }^{\circledR}$ ) 


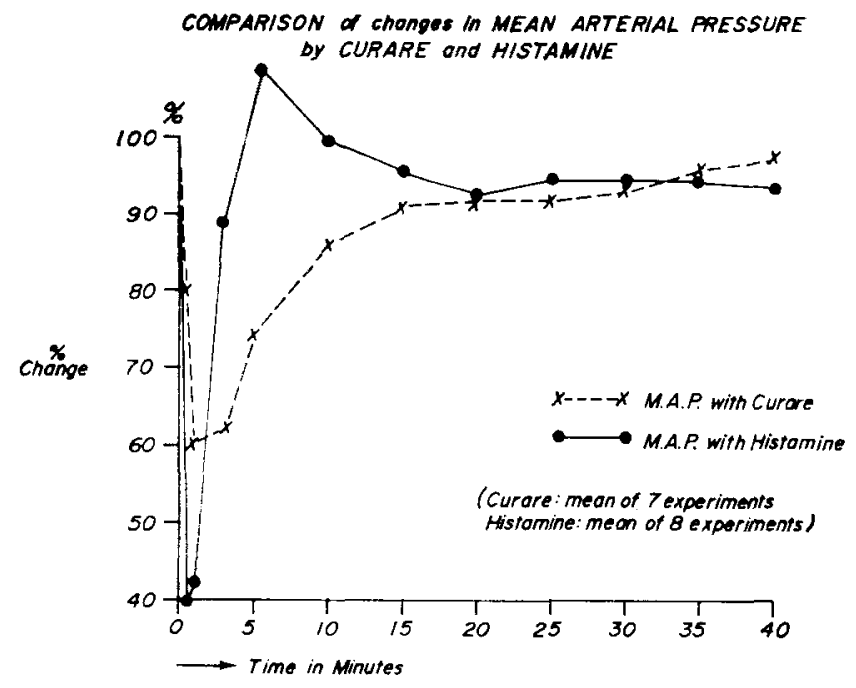

FigURe 6. Comparison of changes in mean arterial pressure following curare and histamine.

CAROIAC OUTPUT and M.A.P affer Bonodyland CURARE

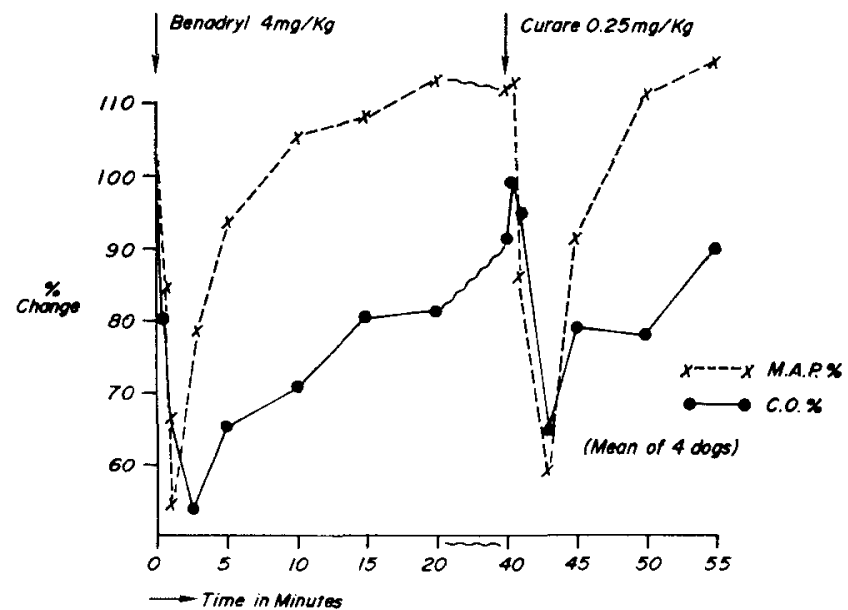

FIGURE 7. The effects of Benadryl on mean cardiac output and mean arterial pressure. Benadryl alone shows a fall in cardiac output and mean arterial pressure. Curare given 40 minutes later was followed by changes in cardiac output and mean arterial pressure as though Benadryl had not been given.

on cardiac output and mean arterial pressure was studied in four dogs (Figure 7). After the administration of Benadryl, $4 \mathrm{mg} / \mathrm{kg}$, alone, there was an immediate fall in cardiac output to 53 per cent of control in three minutes, and of mean arterial pressure to 54 per cent of control within 60 seconds. Curare given 10 to 40 minutes later was followed by a fall in mean arterial pressure to 58 per cent, and a fall in cardiac output to 65 per cent; both recovered within five minutes. 


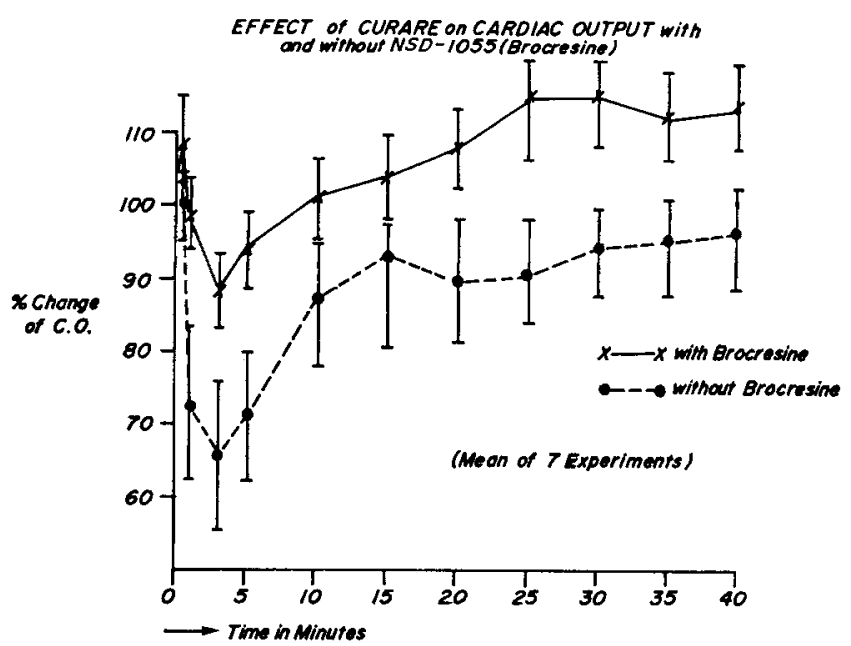

FIGURE 8. In histamine-depleted dogs the changes in cardiac output after injection of curare were approximately one-third of the usual change found in normal dogs.

\section{EFFECT of CURARE On M.AP with and without} BROCRESINE

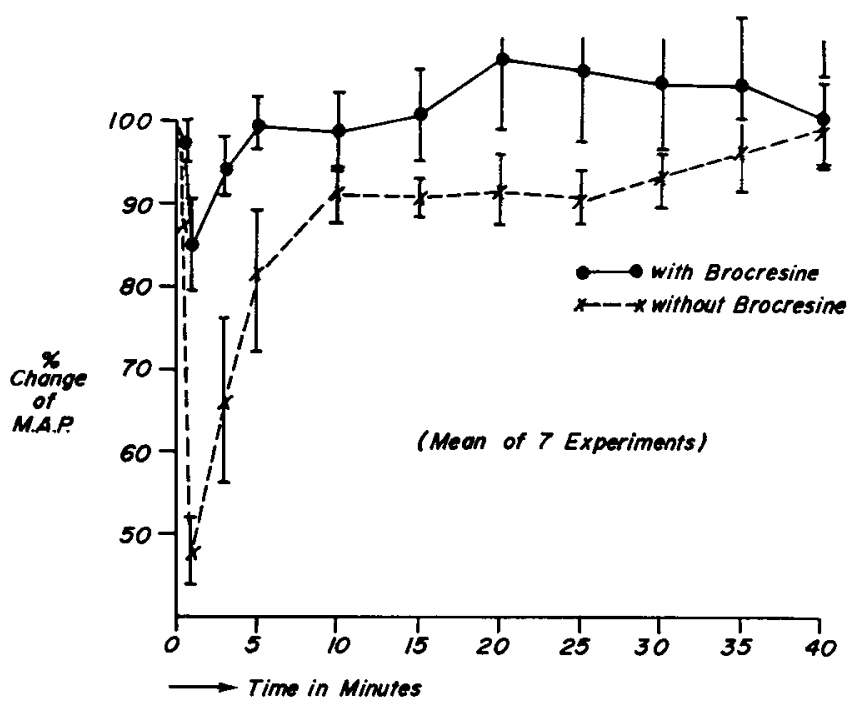

FIGURE 9. In histamine depleted dogs the changes in mean arterial pressure after injection of curare were approximately one-third of the usual change found in normal dogs.

Thus, this dose of Benadryl did not prevent the subsequent histamine-like effects of curare.

The antihistamines have multiple effects, and may act through several mechanisms. Their antagonism to histamine is competitive, i.e. enough antihistamine can overcome the blockade of a given amount of histamine. The $4 \mathrm{mg} / \mathrm{kg}$ 


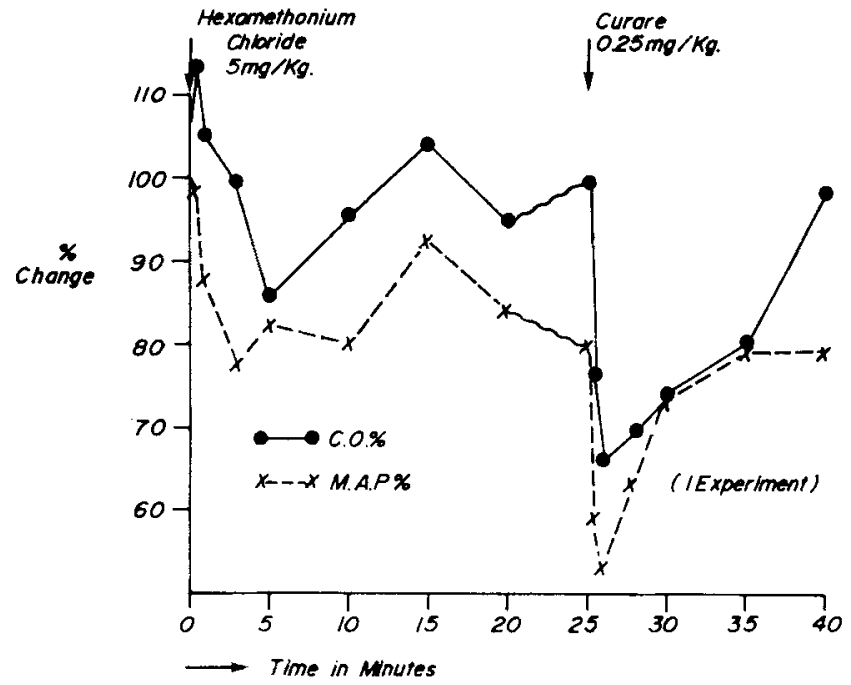

Firiene 10. Provious administration of hexamethonium chloride in a dose of $5 \mathrm{mg} / \mathrm{kg}$ does not affect the change in cardiac output and mean arterial pressure following curare.

Benadryl dose which was used is reported to antagonize the histamine effect in dogs. ${ }^{6}$ If the dosage were increased it might be expected to prevent the effect of histamine. However, it seemed useless to pursue this because of the adverse cardiovascular effect.

\section{Effect of curare in histamine-depleted animals}

In seven histamine-depleted dogs, cardiac output fell to 88 per cent of control in three minutes after curare injection, as compared with a fall in cardiac output to 66 per cent of control in three minutes after curare injection in normal dogs (Figure 8). In the histamine-depleted dogs, the mean arterial pressure fell to 85 per cent within one minute, as compared with a fall to 48 per cent in one minute in normal dogs ( Figure 9 ).

Thus, injection of curarc in histamine-depleted dogs produces changes in cardiac output and mean arterial pressure of approximately one-third of change which occurs in untreated dogs.

\section{The ganglionic blocking action of curare}

Experiments in two dogs showed that previous administration of hexamethonium chloride in a dose of $5 \mathrm{mg} / \mathrm{kg}$ did not affect the change in cardiac output and mean arterial pressure due to curare. ${ }^{6}$ The injection of curare still produced a fall in mean arterial pressure of 50 per cent, and a fall in cardiac output to 65 per cent of control level within 30 seconds (Figure 10). This suggests that the effect of curare upon cardiac output and mean arterial pressure is not due to its ganglionic blocking action. 


\section{Discussion}

Curare can cause a fall in arterial pressure and cardiac output with or without the presence of halothane. Factors through which cardiac output and blood pressure may be affected are: histamine release, ${ }^{1,2,3}$ ganglionic blockade, ${ }^{11}$ or direct myocardial depression. ${ }^{12}$ Therefore, the precise etiology of circulatory changes following administration of curare is difficult to determine.

Small intravenous doses of curare were shown in this study to produce histamine release, with consequent reduction in cardiac output and hypotension in the dog. Histamine decreases arterial pressure and cardiac output by pooling of blood in the splanchnic portal area, and in the peripheral vascular bed. ${ }^{13}$

It has also been shown that curare can produce a decrease in arterial pressure and cardiac output despite prior ganglionic blockade by hexamethonium chloride.

In this study the fall in cardiac output and mean arterial pressure which resulted from the intravenous injection of curare in dogs appears to be related to the endogenous release of histamine.

It was shown recently that in man $^{14}$ injection of curare produced a significant rise in plasma histamine levels. However, injection of curare during clinical anaesthesia does not routinely produce severe fall in blood pressure. Thus, the available evidence as to the release of histamine in man and its expected sequelae, is at present inconclusive. Therefore, these findings in the dog should not be loosely extrapolated to clinical situations without further confirmation in man.

\section{Summary}

Continuous dynamic recordings were obtained in 28 experiments from electromagnetic flow meter probes chronically implanted on the ascending aorta of mongrel dogs. Anaesthesia was induced with Surital, maintained with 1 per cent halothane and followed by subsequent injections of d-tubocurarine (DTC). Cardiac output studies were designed to separate the effects of DTC and histamine and compare with antihistamine and with the effects of DTC in histamine-depleted dogs prepared by Brocresine (NSD 1055), a histamine synthesis inhibitor.

DTC decreased cardiac output to 56 per cent of control at five minutes associated with a concomitant fall in the mean arterial pressure to 60 per cent of control value at one minute after injection respectively. These changes in the dog appear to be due to action of endogenous histamine released by the d-tubocurarine.

\section{RÉSUMÉ}

Nous avons fait des enregistrements dynamiques continus au cours de 28 expériences (obtenues) avec des appareils débit-mètres électromagnétiques implantés à demeure dans l'aorte ascendante de chiens mongrels. L'induction de l'anesthésie s'est faite au surital, et l'anesthésie a été maintenue à l'halothane 1 pour cent et à l'aide d'injections subséquentes de d-tubocurarine. Les études du débit cardiaque étaient destinées à réparer les effets de la DTC et de l'histamine et de les comparer à ceux de l'antihistamine et à ceux de la prc chez les chiens 
privés d'histamine par la brocrésine (NDS 1055), un inhibiteur de synthèse de l'histamine.

La DTC a diminué le débit cardiaque à 56 pour cent du contrôle obtenu après 5 minutes, ceci associé à une chute concomittante de la pression artérielle moyenne à 60 pour cent du contrôle obtenu une minute après l'injection. Ces changements chez le chien semblent dùs à l'action de l'histamine endogène libérée par la d-tubocurarine.

\section{ACKNOWLEDGMENTS}

The authors wish to thank Professor Lucien E. Morris for his encouragement and guidance.

We are grateful to Dr. Earl English for the measurements of histamine.

\section{REFERENCES}

1. Alam, M.; Aniep, G. V.; Barsoum, G. S.; Talati, M.; \& Wieninger, E. Liberation of histamine from the skeletal muscle by curare. J. Physiol. 95: 148-158 (1939).

2. Murphy, Patrick. Histamine in anaesthesia. Brit. J. Anaesth. 34: 397 (1962).

3. Westgate, H. D. \& Van Bergen, F. H. Changes in histamine blood levels following d-tubocurarine administration. Canad. Anaesth. Soc. J. 9: Nov. 6 ( 1962 ).

4. Feldberg, W. Review article on some physiological aspects of histamine. J. Pharm. (London) 6: 281 (1954).

5. Keel, C. C. \& Neil, E. Applied Physiology, (Samson Wright) 10th Ed., 513; LondonOxford Univ. Press (1961).

6. Imatsuki, K.; Yusa, T.; \& Kataoka, Y. Effect of muscle relaxation on ventricalar contractile force in dogs. Tohoku J. Exp. Med. 86: 9-18 (1965).

7. Levine, R. J.; Sato, T. L.; \& Sjoerdosma, A. Inhibition of histamine synthesis in the rat. Biochem. Pharm. 14: 139-149 (1965).

8. Scher, A. M.; Zepeda, J.; \& Brown, O. F. Squarewave electromagnetic flowmeter employing commercially available recorder. J. Appl. Physiol. 18: 1265-1267 (1963).

9. Levine, R. J. Histamine synthesis in man. Science. 1017-8, Nov. 25 (1966).

10. Shore, P. A.; Burkhalter, A.; \& CohN, V. H. A method for the fluorometric assay of histamine in tissues. J. Pharm. Exp. Therap. 127: 182 (1959).

11. GuYton, A. C. \& Reeder, R. C. Quantitative studies on the autonomic action of curare. J. Pharmacol. Exp. Therap. 98: 188-193, Feb. (1950).

12. Dowdy, E. G.; Duggar, P. N.; \& Fabran, L. W. Effect of neuromuscular blocking agents on isolated digitalized mammalian heart. Anesth. \& Analg. 44: 608-615, Sept.-Oct. (1965).

13. Goodman, L. S. \& Gilman, A. The pharmacological basis of therapeutics. MacMillan Co. N.Y. 2nd Ed. 602 (1965).

14. Gerecke, W. B.; Imasato, Y.; \& Keats, A. S. Histamine release by drugs used in association with anaesthesia in man. Abstract A.S.A. Annual Meeting (1959). 